\title{
Triiodothyronine affects the alternative splicing of thyroid hormone receptor alpha $\mathrm{mRNA}$
}

\author{
D C Timmer, O Bakker and W M Wiersinga
}

Department of Endocrinology and Metabolism, F5-171, Academic Medical Center, Meibergdreef 9, 1105 AZ Amsterdam, The Netherlands

(Requests for offprints should be addressed to O Bakker; Email: O.Bakker@amc.uva.nl)

\begin{abstract}
The c-erbA $\alpha$ gene encodes two thyroid hormone receptors, TR $\alpha 1$ and TR $\alpha 2$, that arise from alternative splicing of the TR $\alpha$ pre-mRNA. TR $\alpha 2$ is not able to bind triiodothyronine $\left(\mathrm{T}_{3}\right)$ and acts as a weak antagonist of TRs. It has been suggested that the balance of TR $\alpha 1$ to TR $\alpha 2$ is important in maintaining homeostasis. Here, we study the effect of thyroid hormone on the splicing of TR $\alpha$ under various conditions in HepG2 cells. First, $\mathrm{T}_{3}$ was added to HepG2 cells that endogenously express TR $\alpha$. This resulted in a decrease in the TR $\alpha 1$ :TR $\alpha 2 \mathrm{mRNA}$ ratio after the addition of $10^{-8} \mathrm{M}$ or $10^{-7} \mathrm{M} \mathrm{T}_{3}$. Then, HepG2 cells were incubated with sera from hypothyroid or hyperthyroid patients. Sera from hyperthyroid patients $(n=6)$ decreased the TR $\alpha 1: T R \alpha 2$ ratio compared with HepG2 cells incubated with sera from euthyroid patients $(n=8)$. Sera from hypothyroid patients $(n=6)$ had no effect on the TR $\alpha 1: T R \alpha 2$ ratio but supplementation with $T_{3}$ caused a decrease in the ratio. Finally, we tested sera from patients with nonthyroidal illness (NTI; $n=17$ ) which showed no effect on TR $\alpha$ splicing when compared with
\end{abstract}

controls. Free thyroxine levels in sera from hypo-, eu-, and hyperthyroid patients, but not that of NTI patients, were negatively correlated $(P<0 \cdot 01)$ to the TR $\alpha 1: T R \alpha 2$ ratio. We next studied the expression of the splicing factors hnRNP A1 and ASF/SF2 (SF2) in relation to the splicing of the TR $\alpha$ gene. In HepG2 cells incubated with NTI sera a negative relationship was found between the ratio of hnRNP A1:SF2 and the TR $\alpha 1: T R \alpha 2$ ratio. A high hnRNP A1:SF2 ratio is associated with the use of the distal 5 '-splice site. The splicing direction should then change towards TR $\alpha 2$, which is indeed the case. Rev-ErbA, which is partly complementary to TR $\alpha 2$ and could therefore interfere in the splicing process, did not relate to the TR $\alpha 1: T R \alpha 2$ ratio.

In conclusion, high $\mathrm{T}_{3}$ levels induce a low TR $\alpha 1$ :TR $\alpha 2$ ratio which could protect the cell from excessive $\mathrm{T}_{3}$-induced gene expression. In vivo, this might be a mechanism to keep tissues relatively euthyroid during high serum $\mathrm{T}_{3}$ levels.

Journal of Endocrinology (2003) 179, 217-225

\section{Introduction}

Thyroid hormone exerts its actions primarily by binding to thyroid hormone receptors (TRs) that bind to thyroid hormone response elements in the regulatory region of a gene thereby modifying gene expression. Five different TR isoforms are known $(\alpha 1, \alpha 2, \beta 1, \beta 2, \beta 3)$ which are derived from the genes c-erbA $\alpha$ and c-erbA $\beta$ respectively (Lazar 1993, Williams 2000). The c-erbAa gene encodes two variants that differ at their C-terminal end by the use of an alternative splice site in exon 9. TR $\alpha 1$ is a functional receptor that binds triiodothyronine $\left(\mathrm{T}_{3}\right)$ whereas $T R \alpha 2$ does not bind $\mathrm{T}_{3}$ and may have a dominant negative effect. TR $\alpha 2$ can exert its dominant negative activity either by competing for TR binding to thyroid hormone response elements (TREs) on DNA (Mitsuhashi et al. 1988, Burgos-Trinidad \& Koenig 1999) or via other mechanisms that do not require binding to a TRE (Liu et al. 1995).

$\mathrm{TR} \alpha 2^{-/-}$mice overexpress $\mathrm{TR} \alpha 1$ and are hypothyroid but show a complex phenotype with features of both hypo- and hyperthyroidism (Salto et al. 2001). A disturbance in the balance of the TR $\alpha 1: T R \alpha 2$ ratio may be responsible for the changes in thyroid hormone sensitivity of the different tissues. Moreover, mice that lack all TR $\alpha$ isoforms have an increased sensitivity to thyroid hormone, possibly due to the absence of the silencing effect of the dominant negative TR $\alpha 2$ (Macchia et al. 2001). We hypothesized that $T_{3}$ might have an effect on the alternative splicing of TR $\alpha$ mRNA by changing the balance towards TR $\alpha 2$ in the case of high $T_{3}$ levels. This might then counterbalance excessive $\mathrm{T}_{3}$-induced gene transcription during hyperthyroid conditions. We therefore tested the effect of the addition of $\mathrm{T}_{3}$ on endogenously expressed TR $\alpha 1$ and TR $\alpha 2$ in HepG2 cells. Subsequently, we also looked at the effect of adding sera from patients who were hyperthyroid or hypothyroid. We used HepG2 cells as a model, for these cells have previously been used to study the uptake, metabolism and action of thyroid hormone and have proven to be a suitable model for thyroid hormone handling by the human liver 
(Bartalena et al. 1992, van Stralen et al. 1996). Induction of the low $\mathrm{T}_{3}$ syndrome in rats by fasting alters the balance between TR $\alpha 1$ and TR $\alpha 2$ in liver due to increased expression of TR $\alpha 2$ (Bakker et al. 1998). This leads to the hypothesis that serum from patients with nonthyroidal illness (NTI) might also have an effect on the splicing process of TR $\alpha$ and therefore we also tested sera of NTI patients in our HepG2 model.

It is likely that there is a control of TR $\alpha 1$ and TR $\alpha 2$ mRNA levels by regulation of alternative splicing of the TR $\alpha$ pre-mRNA, and splicing factors may play a role in the selection of the alternative splice site of the TR $\alpha$ pre-mRNA. Certain components of the general splicing mechanism, such as the family of serine-arginine (SR) proteins, affect splice site selection in a dose-dependent manner; they are counteracted by hnRNP A1 and related proteins (Mayeda \& Krainer 1992, Hanamura et al. 1998). The ratio of SR proteins and hnRNP A1-like proteins is therefore an important determinant for alternative $5^{\prime}$ splice-site selection in transfected cells (Caceres et al. 1994). The identification of a splicing enhancer element (SE 2 2) within the final intron of TR $\alpha 2$ mRNA that stimulates TR $\alpha 2$ mRNA splicing and interacts with ASF:SF2 (SF2) supports the idea that these splicing factors are involved (Hastings et al. 2001).

Another interesting feature of the erbA $\alpha$ locus is the presence of a third gene, Rev-ErbA $\alpha$ (RevErb), encoded on the opposite strand of the erbAa (Lazar et al. 1989). The 3'-end of RevErb overlaps with sequences coding for TR $\alpha 2$ but not for TR $\alpha 1$. The fact that RevErb mRNA is partially complementary to TR $\alpha 2$ mRNA could indicate that it is involved in a possible regulatory mechanism for TR $\alpha$ mRNA processing. In vitro splicing towards TR $\alpha 2$ pre-mRNA is inhibited by the addition of an excess of antisense RNAs containing the $3^{\prime}$-end of RevErb mRNA (Munroe \& Lazar 1991). RevErb is also associated with an increase in the ratio of TR $\alpha 1$ to TR $\alpha 2$ mRNA in differentiating adipocytes (Chawla \& Lazar 1993). Consequently, another study aim was to evaluate possible involvement of SF2, hnRNP A1 and RevErb in the splicing process of TR $\alpha$ pre-mRNA.

\section{Patients and Methods}

\section{Materials and methods}

Materials $\mathrm{T}_{3}$ was obtained from Sigma Chemical Co. (St Louis, MO, USA) and dissolved in $5 \mathrm{mM} \mathrm{NaOH}$ to a concentration of $1 \mathrm{mg} / \mathrm{ml}$. It was further diluted in E/MEM (Biowhittaker, Verviers, Belgium) and stored at $-20{ }^{\circ} \mathrm{C}$.

Cell culture The human hepatoma cell line, HepG2, was obtained from the ATCC (\#HB 8065, American Type Culture Collection, Rockville, MD, USA). For the first experiment cells were cultured in E/MEM supplemented with $10 \mathrm{U} / \mathrm{ml}$ penicillin/streptomycin/fungizone $(\mathrm{P} / \mathrm{S} / \mathrm{F})$ and 5\% fetal calf serum (FCS) (all from Biowhittaker). Cells were plated in 6-well plates and reached approximately $70 \%$ confluence after $18 \mathrm{~h}$. Medium was then changed to incubation medium with 5\% FCS and an increasing amount of $\mathrm{T}_{3}\left(10^{-9}\right.$ to $\left.10^{-7} \mathrm{M}\right)$. HepG2 cells were incubated with each concentration of $\mathrm{T}_{3}$ (repeated six times) for a further $24 \mathrm{~h}$ after which RNA was isolated.

The second experiment was performed with sera from hypothyroid and hyperthyroid patients and euthyroid controls. HepG2 cells were incubated in 24-well plates containing E/MEM supplemented with $10 \mathrm{U} / \mathrm{ml} \mathrm{P} / \mathrm{S} / \mathrm{F}$ and $10 \%$ serum. Each serum sample was tested in duplicate for $24 \mathrm{~h}$.

In the third experiment sera from two hypothyroid patients were tested in triplicate with increasing amounts of $\mathrm{T}_{3}\left(10^{-9}\right.$ to $\left.10^{-7} \mathrm{M}\right)$.

In the fourth experiment we incubated HepG2 cells with E/MEM containing $10 \mathrm{U} / \mathrm{ml} \mathrm{P/S} / \mathrm{F}$ and $10 \%$ serum from NTI patients (groups II and III) or healthy controls (group I). We isolated cells after 5, 10 and $24 \mathrm{~h}$ incubation. All samples in this experiment were tested in triplicate. Sera were assayed in four separate runs; each run contained 2 serum samples from groups I-III.

Patients Sera were collected from 8 healthy volunteers, 6 hypothyroid (thyrotropin $(\mathrm{TSH})>4 \mathrm{mU} / \mathrm{l}$, free thyroxine $\left.\left(\mathrm{fT}_{4}\right)<10 \mathrm{pmol} / \mathrm{l}\right)$ patients and 6 hyperthyroid (TSH $\left.<0.4 \mathrm{mU} / 1, \mathrm{fT}_{4}>23 \mathrm{pmol} / \mathrm{l}\right)$ patients.

Additionally, we collected sera from 24 patients hospitalized at the Department of Internal Medicine of our institute. Excluded were patients with thyroid or pituitary/hypothalamic diseases, or those using drugs known to interfere with thyroid hormone metabolism or regulation. Diagnoses of the patients admitted to the study were: infectious disease $(n=7)$, renal insufficiency $(n=6)$, cancer $(n=5)$, liver disease $(n=2)$, multiple sclerosis $(n=1)$, gastrointestinal disease $(n=2)$ and venous thrombosis $(n=1)$. Sera from 8 healthy volunteers acted as controls in this experiment (group I). Sera of patients were divided into two groups: group II with normal serum $\mathrm{T}_{3}$ and $\mathrm{T}_{4}$ levels $\left(\mathrm{T}_{3} \geq 1 \cdot 3 \mathrm{nmol} / 1, \mathrm{~T}_{4} \geq 75 \mathrm{nmol} / 1, n=7\right)$ and group III with subnormal $\mathrm{T}_{3}$ and normal or subnormal $\mathrm{T}_{4}$ levels $\left(\mathrm{T}_{3}<1.3 \mathrm{nmol} / 1, n=17\right)$. Sera were stored at $-20{ }^{\circ} \mathrm{C}$.

Assays Serum $\mathrm{T}_{3}$ and $\mathrm{T}_{4}$ were measured with in-house RIAs (Wiersinga \& Chopra 1982). Free $\mathrm{T}_{4}$ was measured by a two-step fluoroimmunoassay (DELFIA; Wallac, Turku, Finland). TSH was measured with an immunofluorometric assay (DELFIA). A commercial enzyme immunoassay (Pelikine Compact human IL-6 ELISA kit, CLB, Amsterdam, The Netherlands) was used to measure interleukin-6 (IL-6) with a sensitivity of $0.5-$ $1 \mathrm{pg} / \mathrm{ml}$. 
RT-PCR Total RNA was isolated with the RNeasy isolation system (Qiagen $\mathrm{GmbH}$, Hilden, Germany) and reverse transcribed into single-stranded cDNA using the First Strand cDNA synthesis kit with random primers (Roche Molecular Biochemicals, Mannheim, Germany). Real-time PCR reactions were performed in a LightCycler (Roche Molecular Biochemicals). TR $\alpha 1$ and TR $\alpha 2$ were simultaneously detected in the same sample using sequence-specific hybridization probes and a LightCycler-FastStart DNA Master Hybridization Probes kit (Roche). Probes, primers and program were as previously described (Bakker 2001). $\beta$-Actin, hnRNP A1 and SF2 were measured using the LightCycler-DNA Master SYBR Green kit and RevErb with the LightCycler Faststart DNA master SYBR Green kit. We designed primer pairs for hnRNP A1 (sense: $5^{\prime}$-CATGACTGAC CGAGGCAGTG-3'; antisense: 5'-GGCTGGATGAAG CACTAGCC-3') and RevErb (sense: $5^{\prime}$-GCTCGGGC ATGGAGAATTC- $3^{\prime}$; antisense: $5^{\prime}$-CCAGAGGCTCA TCTTGGAAT- $3^{\prime}$ ). Specificity of the product was checked by gel electrophoresis. Primers for ASF:SF2 and $\beta$-actin were as described (Bouaboula et al. 1992, Bai et al. 1999). For each mRNA assayed, a sequence-specific standard was generated and used in the range of $0 \cdot 1-$ $1000 \mathrm{fg} / 20 \mu \mathrm{l}$. The PCR reactions were cycled with the following programs: $\beta$-actin: denaturation at $95^{\circ} \mathrm{C}$ for $10 \mathrm{~s}, 45$ cycles of $0 \mathrm{~s}$ at $95{ }^{\circ} \mathrm{C}, 5 \mathrm{~s}$ at $52^{\circ} \mathrm{C}, 10 \mathrm{~s}$ at $72{ }^{\circ} \mathrm{C}$; hnRNP A1: denaturation at $95^{\circ} \mathrm{C}$ for $10 \mathrm{~s}, 45$ cycles of 0 s at $95{ }^{\circ} \mathrm{C}, 5$ s at $50{ }^{\circ} \mathrm{C}, 10 \mathrm{~s}$ at $72{ }^{\circ} \mathrm{C}$; and SF2: $95^{\circ} \mathrm{C}$ for $10 \mathrm{~s}, 45$ cycles of $0 \mathrm{~s}$ at $95^{\circ} \mathrm{C}, 5 \mathrm{~s}$ at $50{ }^{\circ} \mathrm{C}, 10 \mathrm{~s}$ at $72{ }^{\circ} \mathrm{C}$, $5 \mathrm{~s}$ at $80^{\circ} \mathrm{C}$, all with a final $\mathrm{MgCl}_{2}$ concentration of $5 \mathrm{mM}$. The following program was used for measuring RevErb mRNA: $95{ }^{\circ} \mathrm{C}$ for $600 \mathrm{~s}, 45$ cycles of $0 \mathrm{~s}$ at $95^{\circ} \mathrm{C}, 5 \mathrm{~s}$ at $50{ }^{\circ} \mathrm{C}, 10 \mathrm{~s}$ at $72{ }^{\circ} \mathrm{C}, 5 \mathrm{~s}$ at $81{ }^{\circ} \mathrm{C}$. The final concentration of $\mathrm{MgCl}_{2}$ was $4 \mathrm{mM}$. Melting curves were analyzed with continuous fluorescence reading. From the standard curve generated by measurements taken during the exponential phase of the amplification, the amount of mRNA in each sample was determined. All results were normalized to the amount of $\beta$-actin mRNA and are expressed as relative units.

Western blots HepG2 cells were cultured in $75 \mathrm{~cm}^{2}$ flasks for $24 \mathrm{~h}$ in E/MEM containing 5\% FCS in the presence of $10^{-7} \mathrm{M} \mathrm{T}_{3}$ or without $\mathrm{T}_{3}$ (with only diluted $\mathrm{NaOH}$ in E/MEM as a control). Cells were washed two times with ice-cold PBS and a whole cell extract was made by scraping the cells in $1 \mathrm{ml}$ homogenization buffer (0.25 M sucrose, $10 \mathrm{mM}$ HEPES, $25 \mathrm{mM} \mathrm{KCl}, 1 \mathrm{mM}$ EDTA, 10\% glycerol containing spermine, spermidine and Complete protease inhibitor (Roche Molecular Biochemicals)). The cells were then disrupted at 6500 r.p.m. for $60 \mathrm{~s}$ in a MagNA Lyser (Roche Molecular Biochemicals) with Green Beads (ceramic beads, Roche Molecular Biochemicals). Subsequently, $20 \mu \mathrm{l}$ protein suspension in loading buffer were loaded onto a 10\% SDS-PAGE gel.

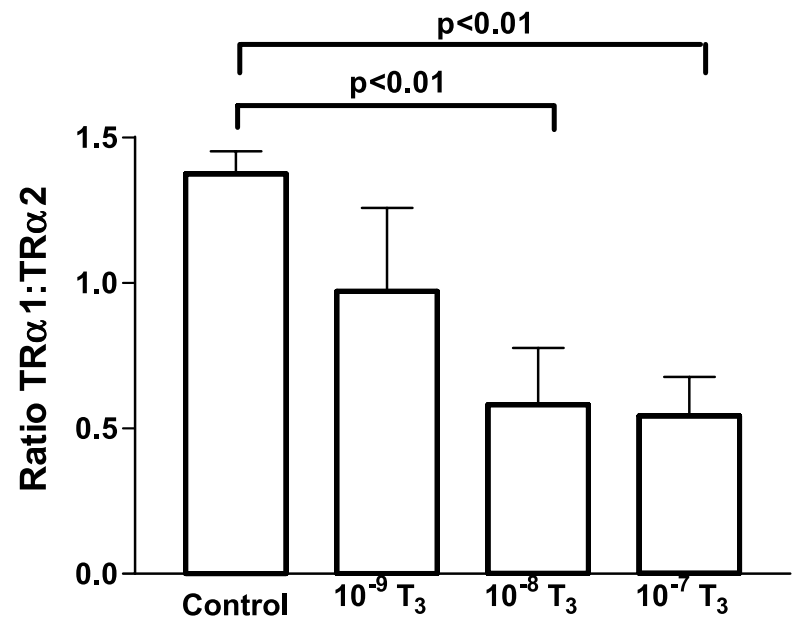

Figure 1 HepG2 cells were incubated with increasing amounts of $\mathrm{T}_{3}\left(10^{-9} \mathrm{M}\right.$ to $\left.10^{-7} \mathrm{M}\right)$ for $24 \mathrm{~h}$ before isolation of mRNA. The effect on the endogenous TR $\alpha 1: T R \alpha 2$ mRNA ratio is shown. Values are means \pm S.E.M. $(n=6)$. $P$ values were calculated with the Mann-Whitney $U$ test.

TR $\alpha 1$ and TR $\alpha 2$ were detected as described by ZandiehDoulabi et al. (2003), using monoclonal antibodies.

Data analysis Differences between groups were analyzed with the Mann-Whitney U test. Pearson's coefficient of correlation was used for evaluation of the relationship between the TR $\alpha 1: T R \alpha 2$ ratio and the hnRNP A1:SF2 ratio and for correlations of serum $\mathrm{T}_{3}, \mathrm{~T}_{4}$ and $\mathrm{f} \mathrm{T}_{4}$ with the TR $\alpha 1$ :TR $\alpha 2$ ratio. Spearman's correlation coefficient was used to analyze the correlation between IL- 6 and $\mathrm{T}_{3}$.

\section{Results}

In the first experiment we tested if the addition of $\mathrm{T}_{3}$ had an effect on the endogenous $\mathrm{TR} \alpha$ mRNA expression and/or the alternative splicing process of $\operatorname{TR} \alpha$ in HepG2 cells. The amount of $T_{3}$ in the FCS is in the picomolar range which is well below the $K_{\mathrm{d}}$ of the thyroid hormone receptor and therefore unlikely to cause interference. Incubation of cells with concentrations of $10^{-8} \mathrm{M}$ and $10^{-7} \mathrm{M} \mathrm{T}_{3}$ significantly decreased the ratio of TR $\alpha 1$ to TR $\alpha 2$ (Fig. 1). The change in the TR $\alpha 1: \operatorname{TR} \alpha 2$ ratio was confirmed on a Western blot. After incubation of HepG2 cells with $10^{-7} \mathrm{M} \mathrm{T}_{3}$ the TR 1 1:TR $\alpha 2$ ratio at the protein level decreased from 0.98 to 0.61 (Fig. 2). The mRNA ratio of the splicing factors hnRNP A1:SF2 did not differ when $T_{3}$ was added. There was also no effect of $\mathrm{T}_{3}$ on RevErb mRNA expression.

The second experiment was performed to evaluate the effects of human euthyroid, hyperthyroid or hypothyroid serum samples on the expression of TR $\alpha$ in HepG2 cells. Hypothyroid sera contained lower levels of $T_{3}$ and $T_{4}$ 


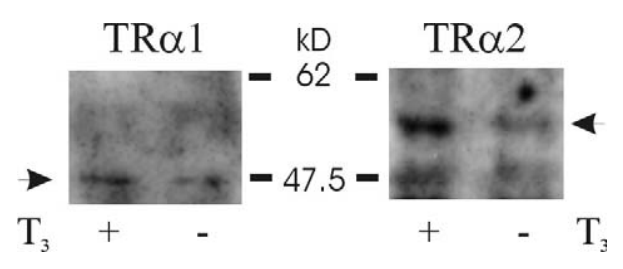

\begin{tabular}{c|crc} 
& $\mathbf{T R} \boldsymbol{\alpha} \mathbf{1}$ & $\mathbf{T R} \boldsymbol{\alpha} \mathbf{2}$ & $\mathbf{T R} \boldsymbol{\alpha} \mathbf{1 : T R} \boldsymbol{\alpha} \mathbf{2}$ \\
\hline$+\mathbf{T}_{\mathbf{3}}$ & 5444 & 8929 & 0.61 \\
$-\mathbf{T}_{\mathbf{3}}$ & 4569 & 4647 & 0.98
\end{tabular}

Figure 2 (Upper panel) Western blots were prepared with whole cell extract of HepG2 cells incubated with or without $10^{-7} \mathrm{M} \mathrm{T}_{3}$. Blots were then incubated with monoclonal antibodies against TR $\alpha 1$ or TR $\alpha 2$. The arrows indicate the specific bands of $46 \mathrm{kDa}$ for TR 1 and $58 \mathrm{kDa}$ for TR $\alpha 2$. (Lower panel) The relative light units of each band are given and the TR $\alpha 1: \operatorname{TR} \alpha 2$ ratio is calculated.

compared with euthyroid sera whereas hyperthyroid sera had increased levels of $\mathrm{T}_{3}$ and $\mathrm{T}_{4}$ (Table 1 ). Incubation of HepG2 cells with hyperthyroid sera induced a decrease in the TR $\alpha 1: T R \alpha 2$ ratio whereas incubation with hypothyroid sera did not have an effect (Fig. 3). No difference was found in total TR $\alpha$ mRNA expression between the three groups. We then analyzed the mRNA expression of RevErb and the splicing factors hnRNP A1 and SF2 and found no differences in expression between the three groups. Furthermore, there was also no correlation with the TR $\alpha 1: \operatorname{TR} \alpha 2$ ratio. The 10-fold increase in the TR $\alpha 1: T R \alpha 2$ ratio when compared with the first experiment is caused by the addition of $10 \%$ human serum.

The third experiment was performed to test if the high concentration of $\mathrm{T}_{3}$ in the serum of hyperthyroid patients caused the decrease in the TR $\alpha 1: T R \alpha 2$ mRNA ratio in HepG2 cells. We therefore added increasing concentrations of $\mathrm{T}_{3}$ to hypothyroid human serum. After a 24-h incubation of HepG2 cells with this $\mathrm{T}_{3}$-enriched serum, the TR $\alpha 1: T R \alpha 2$ ratio decreased significantly (Fig. 4).

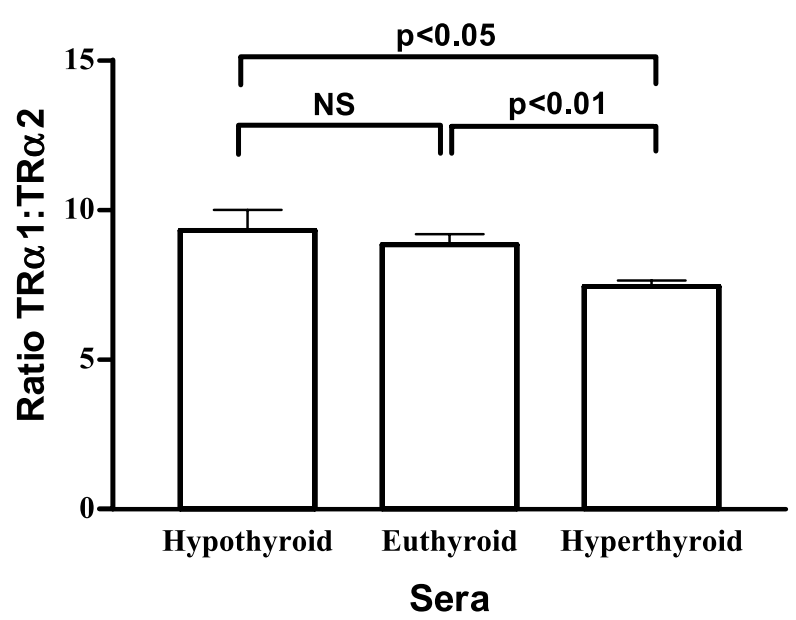

Figure 3 The TR $\alpha 1: T R \alpha 2$ mRNA ratio in HepG2 cells incubated with sera from hypothyroid, euthyroid and hyperthyroid subjects. Values are means \pm S.E.M. $(n=6)$. $P$ values were calculated with the Mann-Whitney $U$ test.

With the fourth experiment we investigated whether the well-known altered concentration of $\mathrm{T}_{3}$ and $\mathrm{T}_{4}$ in the serum of patients with NTI would have an effect on the splicing process of the TR $\alpha$ pre-mRNA in HepG2 cells. Thyroid function tests and IL-6 serum levels of NTI patients and controls are presented in Table 2. Serum IL-6 levels were elevated in the NTI patients when compared with healthy controls, but no differences could be detected within the NTI patient groups. When all patients were analyzed together, a strong correlation was found between total serum $\mathrm{T}_{3}$ and serum IL-6 (Spearman's correlation coefficient, $r=-0 \cdot 61, P<0 \cdot 001)$. We harvested HepG2 cells after 5, 10 and $24 \mathrm{~h}$ of incubation with serum. Since no significant effects on the splicing of $\operatorname{TR} \alpha$ were seen after 5 and $10 \mathrm{~h}$ (data not shown) we only describe the data after $24 \mathrm{~h}$ of incubation. The TR $\alpha 1$ :TR $\alpha 2$ ratio did not change between cells incubated with sera from different groups (Fig. 5A). No differences were found between the different groups for any of the measured mRNAs with the exception of increased RevErb mRNA in NTI patients

Table 1 Thyroid function tests of euthyroid, hypothyroid and hyperthyroid subjects. Values are given as median and range

\begin{tabular}{|c|c|c|c|}
\hline & Hypothyroid & Euthyroid & Hyperthyroid \\
\hline \multicolumn{4}{|l|}{ Parameter } \\
\hline No. $(M, F)$ & $6(0,6)$ & $8(3,5)$ & $6(0,6)$ \\
\hline Age (years) & $35(27-51)$ & $38(24-51)$ & $45(32-56)$ \\
\hline Total $\mathrm{T}_{3}(\mathrm{nmol} / \mathrm{l})$ & $1 \cdot 2(0 \cdot 5-2 \cdot 1)^{\mathrm{a}}$ & $2 \cdot 2(1 \cdot 8-3 \cdot 0)$ & $5 \cdot 9(2 \cdot 7-7 \cdot 9)^{\mathrm{b}}$ \\
\hline Total $\mathrm{T}_{4}(\mathrm{nmol} / \mathrm{l})$ & $35(5-115)^{\mathrm{c}}$ & $110(70-145)$ & $245(210-397)^{\mathrm{b}}$ \\
\hline Free $\mathrm{T}_{4}(\mathrm{pmol} / \mathrm{l})$ & $3 \cdot 2(2 \cdot 0-9 \cdot 6)^{d}$ & $14(12-20)$ & $66(26->70)^{\mathrm{b}}$ \\
\hline $\mathrm{TSH}(\mathrm{mU} / \mathrm{l})$ & $95(12-226)^{d}$ & $1 \cdot 45(0 \cdot 5-2 \cdot 3)$ & $0.035(0.02-0.05)^{e}$ \\
\hline
\end{tabular}

${ }^{\mathrm{a}} P \leq 0.01,{ }^{\mathrm{c}} P \leq 0.05,{ }^{\mathrm{d}} P \leq 0.001$ : hypothyroid compared with euthyroid; ${ }^{\mathrm{b}} P \leq 0.001,{ }^{\mathrm{e}} P \leq 0.05$ :

hyperthyroid compared with euthyroid (Mann-Whitney $U$ test). 


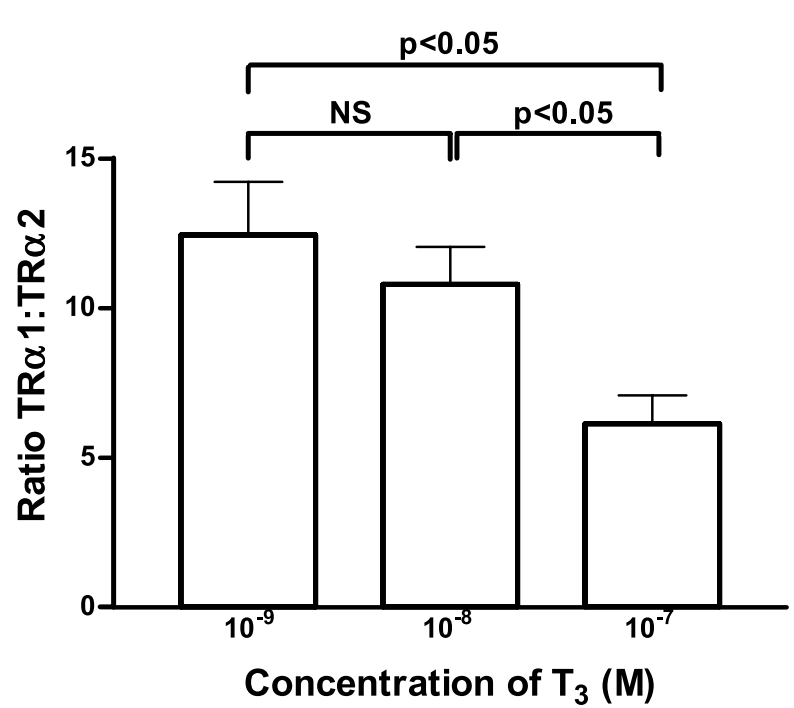

Figure 4 The TR $\alpha 1: T R \alpha 2$ mRNA ratio in HepG2 cells incubated with sera from hypothyroid subjects, supplemented with increasing amounts of $\mathrm{T}_{3}\left(10^{-9} \mathrm{M}\right.$ to $\left.10^{-7} \mathrm{M}\right)$. Values are means \pm S.E.M. $(n=6)$. $P$ values were calculated with the Mann-Whitney $U$ test.

with a subnormal $\mathrm{T}_{3}$ (group III; Fig. $5 \mathrm{~B}$ ). The mRNA expression of RevErb was negatively correlated to the level of serum $\mathrm{T}_{3}(r=-0 \cdot 39, P<0 \cdot 05)$. We did not find a relationship between the TR $\alpha 1: \operatorname{TR} \alpha 2$ ratio and RevErb. Interestingly, although no effect of the individual splicing factors hnRNP A1 and SF2 on the TR $\alpha 1: T R \alpha 2$ ratio was seen, a negative correlation $(r=-0 \cdot 40, P<0 \cdot 05)$ was found between the TR $\alpha 1$ :TR $\alpha 2$ ratio and the ratio of hnRNP A1:SF2 (Fig. 6). No correlation was found between IL-6 and any of the measured mRNAs.

Whereas a clear negative correlation was found between serum $\mathrm{fT}_{4}$ levels of hypothyroid, euthyroid and hyperthyroid patients and the effect of these sera on the TR $\alpha 1$ :TR $\alpha 2$ ratio, this relationship was not observed for NTI sera (Fig. 7).

\section{Discussion}

The balance between TR $\alpha 1$ and TR $\alpha 2$ is important since they are both transcription factors but have opposite effects on $T_{3}$-responsive gene expression (Koenig et al. 1989). Studies in mouse strains that lack both TR $\alpha$ isoforms or only TR $\alpha 2$, have shown an increased sensitivity to $T_{3}$ which is mainly attributed to the abrogation of the constitutive silencing mediated through TR $\alpha 2$ (Macchia et al. 2001, Salto et al. 2001). Although no definite conclusions about the role of TR $\alpha 2$ can be drawn, both studies underline the fact that the balance in the TR $\alpha 1: T R \alpha 2$ ratio may play an important role in the control of growth and homeostasis.

We show here that a high amount of $T_{3}$ decreases the endogenous TR $\alpha 1$ TR $\alpha 2$ ratio in HepG2 cells without affecting the transcription of the total TR $\alpha$ mRNA. This change in the TR $\alpha 1$ :TR $\alpha 2$ mRNA ratio due to $T_{3}$ was also observed at the protein level. When HepG2 cells were exposed to sera from hyperthyroid patients we also found that high thyroid hormone concentrations decreased the TR $\alpha 1$ :TR $\alpha 2$ mRNA ratio. Addition of $\mathrm{T}_{3}$ to sera from hypothyroid patients similarly resulted in a decrease in the TR $\alpha 1: T R \alpha 2$ ratio. This change in the splicing direction towards the dominant negative receptor TR $\alpha 2$ could protect the (HepG2) cell against excessive $\mathrm{T}_{3}$-induced gene expression, despite an extracellular environment containing high levels of $\mathrm{T}_{3}$.

The mechanism behind this effect of $\mathrm{T}_{3}$ is not clear. Unlike the gene encoding the TR $\beta$ isoforms, the gene encoding TR $\alpha$ does not contain a TRE and is therefore probably not under direct thyroid hormone control (Suzuki et al. 1994). Indeed, in our studies $T_{3}$ had no or only minor effects on transcription of the TR $\alpha$ gene, indicating that the effect of $\mathrm{T}_{3}$ on TR $\alpha$ splicing is probably not regulated at the transcriptional level of the gene. Alternative splicing of TR $\alpha$ pre-mRNA could be regulated in various ways. One is the choice of the alternative $5^{\prime}$-splice site, which is mediated by various splicing factors that bind to the alternative splice site but also to adjacent

Table 2 Thyroid function tests and serum IL-6 in controls (group I) and hospitalized patients with normal serum $\mathrm{T}_{3}$ (group II) or subnormal $\mathrm{T}_{3}$ (group III). Values are given as median and range

\begin{tabular}{|c|c|c|c|}
\hline & Group I & Group II & Group III \\
\hline \multicolumn{4}{|l|}{ Parameter } \\
\hline No. $(M, F)$ & $8(3,5)$ & $7(4,3)$ & $17(8,9)$ \\
\hline Age (years) & $40(24-59)$ & $43(18-58)$ & $53(27-79)$ \\
\hline Total $\mathrm{T}_{3}(\mathrm{nmol} / \mathrm{l})$ & $2 \cdot 2(1 \cdot 8-3 \cdot 0)$ & $1 \cdot 6(1 \cdot 3-2 \cdot 4)$ & $0 \cdot 6(0 \cdot 2-1 \cdot 2)^{a, b}$ \\
\hline Total $\mathrm{T}_{4}(\mathrm{nmol} / \mathrm{l})$ & $98(70-145)$ & $110(80-140)$ & $75(35-125)^{\mathrm{c}}$ \\
\hline Free $\mathrm{T}_{4}(\mathrm{pmol} / \mathrm{l})$ & $14(12-20)$ & $15(12-23)$ & $16(9-25)$ \\
\hline $\mathrm{TSH}(\mathrm{mU} / \mathrm{l})$ & $1 \cdot 5(0 \cdot 5-2 \cdot 3)$ & $1 \cdot 5(0 \cdot 3-4 \cdot 0)$ & $2 \cdot 2(0 \cdot 2-5 \cdot 6)$ \\
\hline IL-6 (pg/ml) & $1 \cdot 1(0 \cdot 1-2 \cdot 1)$ & $16 \cdot 3(2 \cdot 5-104 \cdot 0)^{\mathrm{a}}$ & $23.6(3.9-654 \cdot 0)^{a}$ \\
\hline
\end{tabular}


A.

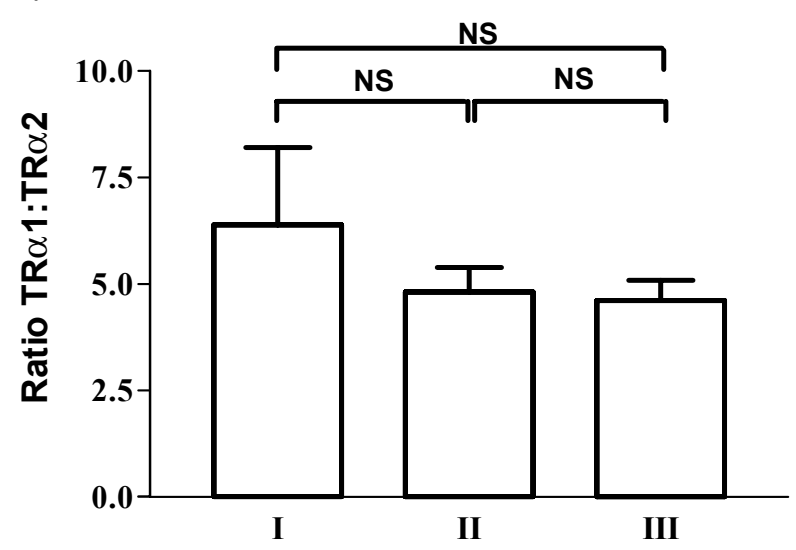

B.

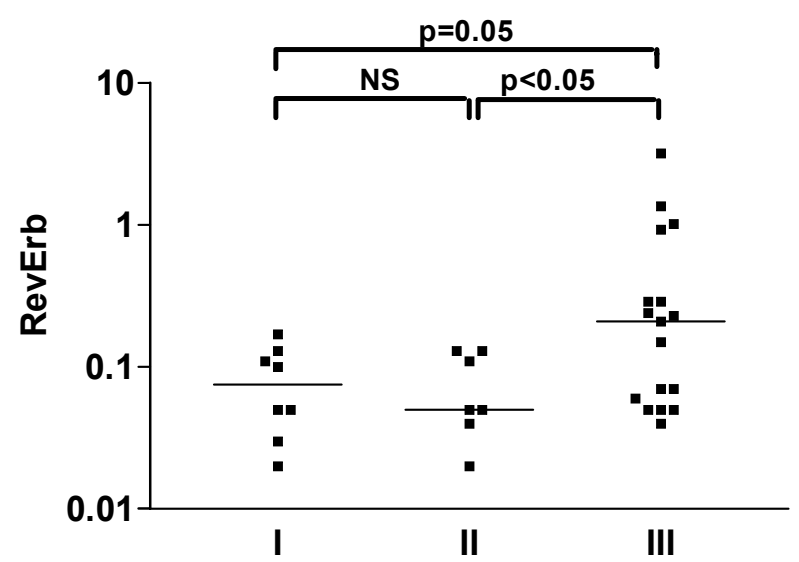

Figure 5 HepG2 cells were incubated with sera from healthy subjects (group I) or NTI patients (group II and III) for $24 \mathrm{~h}$. The effects on the TR $\alpha 1: T R \alpha 2$ mRNA ratio $(\mathrm{A})$ and on RevErb mRNA expression (B) are shown. Values are means \pm S.E.M. $P$ values were calculated with the Mann-Whitney $U$ test. elements which results in expression of TR $\alpha 1$ or TR $\alpha 2$. In the intron of TR $\alpha 2$ a splicing enhancer element (SE $\alpha 2)$ was characterized which stimulates TR $\alpha 2$ mRNA splicing in vitro. SE 22 binds SF2 which indicates that the splicing process might be influenced by binding of specific splicing proteins to this element (Lazar et al. 1989, Laudet et al. 1991, Hastings et al. 2001). $\mathrm{T}_{3}$ added at a concentration of $10^{-9} \mathrm{M}$ increased the hnRNP A1:SF2 ratio in HepG2 cells, which coincided with an increase in TR $\alpha 2$ expression. The TR $\alpha 1: T R \alpha 2$ ratio decreased although not significantly. This is in agreement with experiments that show that a predominance of SF2 over hnRNP A1 promotes the use of the proximal $5^{\prime}$-splice site, which in our case would lead to a high TR $\alpha 1$ :TR $\alpha 2$ ratio. A high hnRNP A1:SF2 ratio results in the use of the distal $5^{\prime}$-splice sites, leading to a low TR $\alpha 1$ :TR $\alpha 2$ ratio. It is known that both SF2 and hnRNP A1 can bind to specific RNA sequences and affect the choice of splice site (Mayeda \& Krainer 1992, Sun et al. 1993, Caceres et al. 1994). Bai et al. (1999) have shown that co-transfection of SF2 with a calcitonin/calcitonin in gene-related peptide (CGRP) gene construct promoted the use of the proximal $3^{\prime}$-splice site, resulting in the inclusion of a terminal calcitonin exon. Co-transfection with hnRNP A1 antagonized the effect of SF2 by stimulating the distal splice site. In our in vitro model only one alternative splice site is present, which is the distal splice site leading to TR $\alpha 2$ that is chosen over polyadenylation of TR $\alpha 1$. The discovery of the intronic enhancer element, SE $\alpha 2$, within the final intron of TR $\alpha 2$ mRNA supports the idea that these splicing factors are involved and that the model proposed for calcitonin would be valid in this case as well (Hastings et al. 2001). However, involvement of other, possibly tissue-specific splicing factors that play a role in the splicing process of the TR $\alpha$ pre-mRNA cannot be ruled out.

Regulation of the splicing process by thyroid hormone could also be mediated via signaling pathways leading to phosphorylation and subsequent activation of splicing factors.

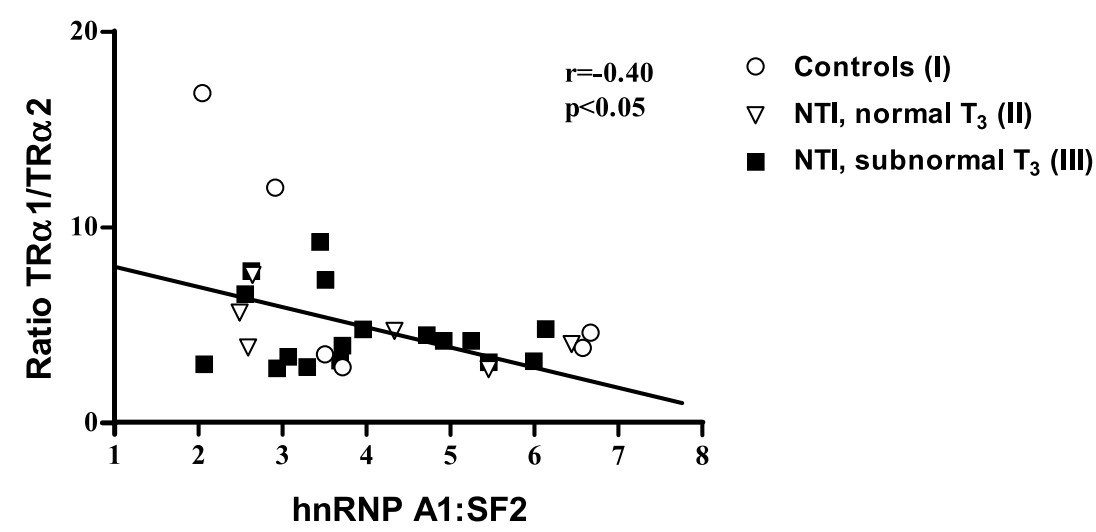

Figure 6 Correlation between endogenous mRNA values of the TR $\alpha 1: T R \alpha 2$ ratio and the hnRNP A1:SF2 ratio in HepG2 cells incubated with serum from NTI patients or controls. 
A.

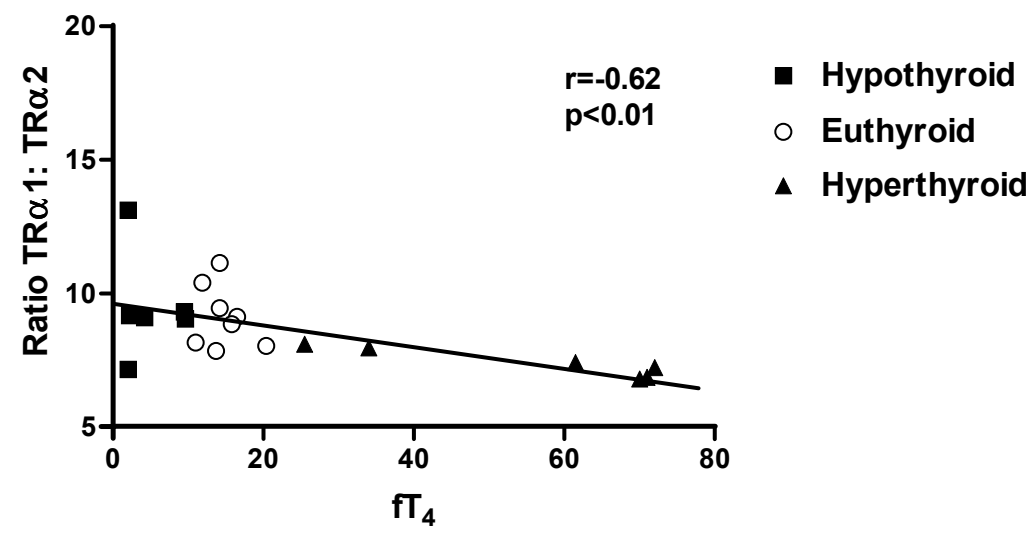

B.

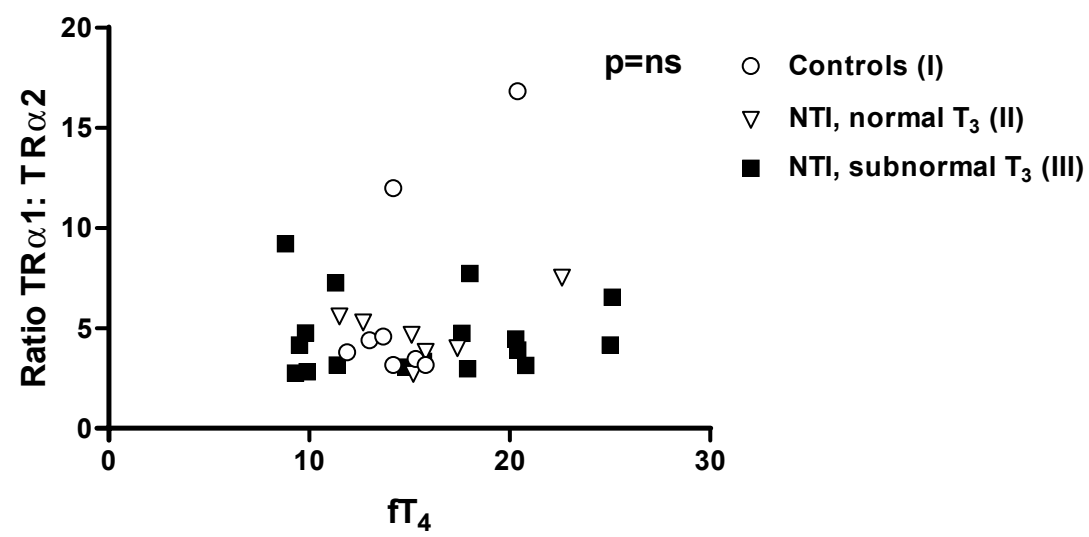

Figure 7 (A) Relationship between serum free $T_{4}$ from hypothyroid, euthyroid and hyperthyroid subjects and the TR $\alpha 1: T R \alpha 2$ mRNA ratio in HepG2 cells incubated with these sera. Free $\mathrm{T}_{4}$ levels of three hyperthyroid patients are $>70 \mathrm{pmol} / \mathrm{l}$. Pearson's correlation coefficient is shown. (B) Correlation between serum free $T_{4}$ levels in healthy subjects (group I) and NTI patients (groups II and III) and the TR $\alpha 1$ :TR $\alpha 2$ ratio in HepG2 cells incubated with these sera.

Phosphorylation of SR proteins by CLK/Sty protein kinase leads to their release from nuclear speckles and enhances protein activity (Colwill et al. 1996). Xiao and Manley (1997) showed that SF2 could only activate splicing in vitro when its serine residues in the RS domain are phosphorylated. It is possible that $\mathrm{T}_{3}$ exerts its effect on splicing by serine phosphorylation of SF2. Since several kinases, such as CLK/Sty, SRPK1, protein kinase (PK) A and PKC are all able to phosphorylate SF2, there are multiple candidates for regulation by $\mathrm{T}_{3}$. Serine phosphorylation of TR isoforms has also been described. For example, TR $\beta 1$ is stabilized by phosphorylation mediated by MAP kinases (MAPKs) via a nongenomic action of $\mathrm{T}_{4}$
(Davis et al. 2000). Chen et al. (2003) have shown that MAPKs also potentiate TR activity. SF2, however, is not a substrate for MAPK although other splicing factors might be involved that could be phosphorylated by MAPK. Jones et al. (1994) have shown a reduction in $T_{3}$-induced gene transcription as a result of reduced TR $\alpha 1$ and TR $\beta 1$ activity due to the use of the serine/threonine kinase inhibitor, H7. In contrast to the effects observed on TR proteins by phosphorylation, no effects of phosphorylation have been described on TR isoform expression.

Another feature that could contribute to regulation of the TR $\alpha$ mRNA processing is RevErb. This anti-sense transcript encodes a nuclear receptor belonging to the 
same superfamily as the thyroid hormone receptors. Only two natural target genes are known, the rat apolipoprotein (apo)A-1 gene and the human RevErb gene itself (Adelmant et al. 1996, Vu-Dac et al. 1998). Since the RevErb mRNA partially overlaps the TR $\alpha 2$ mRNA, a possible role in direct regulation of the $\operatorname{TR} \alpha$ gene expression by RevErb has been suggested. Transfection of a minigene expressing both TR $\alpha$ and RevErb genes, resulted in a twofold increase in the TR $\alpha 1$ :TR $\alpha 2$ ratio as compared with TR $\alpha$ expression without co-expression of RevErb (Hastings et al. 2000). A similar increase in the TR $\alpha 1: T R \alpha 2$ ratio and RevErb mRNA was found in adipocytes that were induced to differentiate in vitro (Chawla \& Lazar 1993). On the other hand, in a differentiating B-cell line, no correlation was found between the TR $\alpha 1$ :TR $\alpha 2$ ratio and RevErb but a positive correlation was found between TR $\alpha 1: T R \alpha 2$ ratio and the RevErb:TR $\alpha 2$ ratio (Hastings et al. 1997). In this case the authors do in fact show a relation between TR $\alpha 1$ and RevErb, since both are divided by TR $\alpha 2$. In our study, we did not find any correlation between RevErb and the TR $\alpha 1$ :TR $\alpha 2$ ratio, suggesting that, at least in this experiment, RevErb mRNA has no influence on the splicing of TR $\alpha$ pre-mRNA. The increased expression of RevErb in HepG2 cells incubated with NTI sera could be the result of low $\mathrm{T}_{3}$ contents in these sera since we also found a negative correlation between serum $\mathrm{T}_{3}$ and RevErb which is of unknown significance.

The low amount of $\mathrm{T}_{3}$ in NTI sera does not seem to have an effect on the splicing process of TR $\alpha$ pre-mRNA. IL-6 levels were elevated in serum of all NTI patients and correlated strongly with serum $T_{3}$, which is in agreement with previous reports (Boelen et al. 1993, Davies et al. 1996). IL-6 has been shown to contribute to the pathogenesis of NTI but the mechanisms have not yet been elucidated (Boelen et al. 1996). In our experiment, serum IL-6 was not related to the TR $\alpha 1: T R \alpha 2$ ratio but we cannot rule out the possibility that IL-6, via co-activators or splicing factors, plays an indirect role in the regulation of the splicing process. HepG2 cells incubated with NTI sera showed a relationship between a high hnRNP A1:SF2 ratio and a low TR $\alpha 1: T R \alpha 2$ ratio which is not related to serum $\mathrm{T}_{3}$. However, this result supports the idea that a certain balance in the splicing factors hnRNP A1 to SF2 is involved in the splicing of $\operatorname{TR} \alpha$.

In conclusion, we have demonstrated that high amounts of $\mathrm{T}_{3}$ in the incubation medium of HepG2 cells, either present in serum or supplemented, lead to a shift in the splicing direction of the endogenous $\operatorname{TR} \alpha$ pre-mRNA towards the dominant negative isoform, TR $\alpha 2$. This suggests a model where the change in splicing direction protects cells against excessive thyroid hormone-regulated gene expression. In vivo, this might provide a mechanism to keep tissues relatively euthyroid despite high serum $\mathrm{T}_{3}$ levels.

\section{Funding}

This work was supported by the Netherlands Organization for Scientific Research (Grant 903-40-194). There is no conflict of interest that would prejudice impartiality.

\section{References}

Adelmant G, Begue A, Stehelin D \& Laudet V 1996 A functional Rev-erb alpha responsive element located in the human Rev-erb alpha promoter mediates a repressing activity. PNAS $\mathbf{9 3}$ 3553-3558.

Bai Y, Lee D, Yu T \& Chasin LA 1999 Control of 3' splice site choice in vivo by ASF/SF2 and hnRNP A1. Nucleic Acids Research 27 1126-1134.

Bakker O 2001 Dual color detection of splice variants of the c-erbA $\alpha$ (thyroid hormone receptor $\alpha$ ) gene. In Rapid Cycle Real-Time PCR: Methods and Applications, pp 91-96. Eds F Meuer, C Wittwer \& K Nakagawara. Berlin, Heidelberg, New York: Springer-Verlag.

Bakker O, Razaki H, de Jong J, Ris-Stalpers C \& Wiersinga WM 1998 Expression of the alpha 1, alpha 2, and beta 1 T3-receptor mRNAs in the fasted rat measured using competitive PCR. Biochemical and Biophysical Research Communications 242 492-496.

Bartalena L, Farsetti A, Flink IL \& Robbins J 1992 Effects of interleukin-6 on the expression of thyroid hormone-binding protein genes in cultured human hepatoblastoma-derived (Hep G2) cells. Molecular Endocrinology 6 935-942.

Boelen A, Platvoet-ter-Schiphorst MC \& Wiersinga WM 1993 Association between serum interleukin-6 and serum 3,5,3'triiodothyronine in nonthyroidal illness. Journal of Clinical Endocrinology and Metabolism 77 1695-1699.

Boelen A, Maas MA, Lowik CW, Platvoet MC \& Wiersinga WM 1996 Induced illness in interleukin-6 (IL-6) knock-out mice: a causal role of IL-6 in the development of the low 3,5,3'triiodothyronine syndrome. Endocrinology 137 5250-5254.

Bouaboula M, Legoux P, Pessegue B, Delpech B, Dumont X, Piechaczyk M, Casellas P \& Shire D 1992 Standardization of mRNA titration using a polymerase chain reaction method involving co-amplification with a multispecific internal control. Journal of Biological Chemistry 267 21830-21838.

Burgos-Trinidad M \& Koenig RJ 1999 Dominant negative activity of thyroid hormone receptor variant alpha2 and interaction with nuclear corepressors. Molecular and Cellular Endocrinology 149 107-114.

Caceres JF, Stamm S, Helfman DM \& Krainer AR 1994 Regulation of alternative splicing in vivo by overexpression of antagonistic splicing factors. Science 265 1706-1709.

Chawla A \& Lazar MA 1993 Induction of Rev-ErbA alpha, an orphan receptor encoded on the opposite strand of the alpha-thyroid hormone receptor gene, during adipocyte differentiation. Journal of Biological Chemistry 268 16265-16269.

Chen SL, Chang YJ, Wu YH \& Lin KH 2003 Mitogen-activated protein kinases potentiate thyroid hormone receptor transcriptional activity by stabilizing its protein. Endocrinology 144 1407-1419.

Colwill K, Pawson T, Andrews B, Prasad J, Manley JL, Bell JC \& Duncan PI 1996 The Clk/Sty protein kinase phosphorylates SR splicing factors and regulates their intranuclear distribution. EMBO Journal 15 265-275.

Davies PH, Black EG, Sheppard MC \& Franklyn JA 1996 Relation between serum interleukin- 6 and thyroid hormone concentrations in 270 hospital in-patients with non-thyroidal illness. Clinical Endocrinology 44 199-205.

Davis PJ, Shih A, Lin HY, Martino LJ \& Davis FB 2000 Thyroxine promotes association of mitogen-activated protein kinase and nuclear thyroid hormone receptor (TR) and causes serine phosphorylation of TR. Journal of Biological Chemistry 275 38032-38039. 
Hanamura A, Caceres JF, Mayeda A, Franza BR Jr \& Krainer AR 1998 Regulated tissue-specific expression of antagonistic pre-mRNA splicing factors. RNA 4 430-444.

Hastings ML, Milcarek C, Martincic K, Peterson ML \& Munroe SH 1997 Expression of the thyroid hormone receptor gene, erbAalpha, in B lymphocytes: alternative mRNA processing is independent of differentiation but correlates with antisense RNA levels. Nucleic Acids Research 25 4296-4300.

Hastings ML, Ingle HA, Lazar MA \& Munroe SH 2000 Posttranscriptional regulation of thyroid hormone receptor expression by cis-acting sequences and a naturally occurring antisense RNA. Journal of Biological Chemistry 275 11507-11513.

Hastings ML, Wilson CM \& Munroe SH 2001 A purine-rich intronic element enhances alternative splicing of thyroid hormone receptor mRNA. RNA 7 859-874.

Jones KE, Brubaker JH \& Chin WW 1994 Evidence that phosphorylation events participate in thyroid hormone action. Endocrinology 134 543-548.

Koenig RJ, Lazar MA, Hodin RA, Brent GA, Larsen PR, Chin WW \& Moore DD 1989 Inhibition of thyroid hormone action by a non-hormone binding c-erbA protein generated by alternative mRNA splicing. Nature 337 659-661.

Laudet V, Begue A, Henry-Duthoit C, Joubel A, Martin P, Stehelin D \& Saule S 1991 Genomic organization of the human thyroid hormone receptor alpha (c-erbA-1) gene. Nucleic Acids Research 19 1105-1112.

Lazar MA 1993 Thyroid hormone receptors: multiple forms, multiple possibilities. Endocrine Reviews 14 184-193.

Lazar MA, Hodin RA, Darling DS \& Chin WW 1989 A novel member of the thyroid/steroid hormone receptor family is encoded by the opposite strand of the rat c-erbA alpha transcriptional unit. Molecular Cell Biology 9 1128-1136.

Liu RT, Suzuki S, Miyamoto T, Takeda T, Ozata M \& DeGroot LJ 1995 The dominant negative effect of thyroid hormone receptor splicing variant alpha 2 does not require binding to a thyroid response element. Molecular Endocrinology 9 86-95.

Macchia PE, Takeuchi Y, Kawai T, Cua K, Gauthier K, Chassande O, Seo H, Hayashi Y, Samarut J, Murata Y, Weiss RE \& Refetoff S 2001 Increased sensitivity to thyroid hormone in mice with complete deficiency of thyroid hormone receptor alpha. PNAS $\mathbf{9 8}$ 349-354.

Mayeda A \& Krainer AR 1992 Regulation of alternative premRNA splicing by hnRNP A1 and splicing factor SF2. Cell 68 365-375.

Mitsuhashi T, Tennyson GE \& Nikodem VM 1988 Alternative splicing generates messages encoding rat c-erbA proteins that do not bind thyroid hormone. PNAS 85 5804-5808.
Munroe SH \& Lazar MA 1991 Inhibition of c-erbA mRNA splicing by a naturally occurring antisense RNA. Journal of Biological Chemistry 266 22083-22086.

Salto C, Kindblom JM, Johansson C, Wang Z, Gullberg H, Nordstrom K, Mansen A, Ohlsson C, Thoren P, Forrest D \& Vennstrom B 2001 Ablation of TRalpha2 and a concomitant overexpression of alpha1 yields a mixed hypo- and hyperthyroid phenotype in mice. Molecular Endocrinology 15 2115-2128.

van Stralen PG, van der Hoek HJ, Docter R, de Jong M, Krenning EP, Everts ME \& Hennemann G 1996 Uptake and metabolism of 3,5, $3^{\prime}$-triiodothyronine and $3,3^{\prime}, 5^{\prime}$ - triiodothyronine by human liver-derived cells: HepG2 cells as a model for thyroid hormone handling by human liver. Journal of Clinical Endocrinology and Metabolism 81 244-248.

Sun Q, Mayeda A, Hampson RK, Krainer AR \& Rottman FM 1993 General splicing factor SF2/ASF promotes alternative splicing by binding to an exonic splicing enhancer. Genes and Development 7 $2598-2608$.

Suzuki S, Miyamoto T, Opsahl A, Sakurai A \& DeGroot LJ 1994 Two thyroid hormone response elements are present in the promoter of human thyroid hormone receptor beta 1. Molecular Endocrinology 8 305-314.

Vu-Dac N, Chopin-Delannoy S, Gervois P, Bonnelye E, Martin G, Fruchart JC, Laudet V \& Staels B 1998 The nuclear receptors peroxisome proliferator-activated receptor alpha and Rev-erb alpha mediate the species-specific regulation of apolipoprotein A-I expression by fibrates. Journal of Biological Chemistry 273 25713-25720.

Wiersinga WM \& Chopra IJ 1982 Radioimmunoassay of thyroxine (T4), 3,5,3'-triiodothyronine (T3), 3,3', 5' -triiodothyronine (reverse T3, rT3), and 3,3'-diiodothyronine (T2). Methods in Enzymology 84 272-303.

Williams GR 2000 Cloning and characterization of two novel thyroid hormone receptor beta isoforms. Molecular Cell Biology 20 8329-8342.

Xiao SH \& Manley JL 1997 Phosphorylation of the ASF/SF2 RS domain affects both protein-protein and protein-RNA interactions and is necessary for splicing. Genes and Development 11 334-344.

Zandieh-Doulabi B, Dop E, Schmeiders M, Schiphorst MP-T, Mansen A, Vennström B, Dijkstra CD, Bakker O \& Wiersinga WM 2003 Zonal expressionof the thyroid hormone receptor \& isoforms in rodent liver. Journal of Endocrinology (In Press).

Received in final form 6 August 2003

Accepted 20 August 2003

Made available online as an

Accepted Preprint 26 August 2003 